\title{
Multiple radiation-induced neurofibromas
}

\section{Figure 1 Coronal cervical spine MRI (A) and sagittal left side (B)}

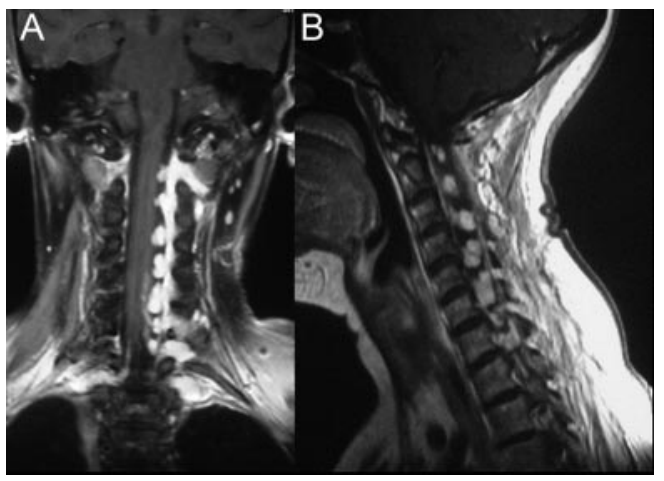

MRI showing neurofibromas from C2 to T1, predominantly on the irradiated side. No neurofibromas were observed in the remaining spine.

\section{Figure 2 Tumor histopathology}

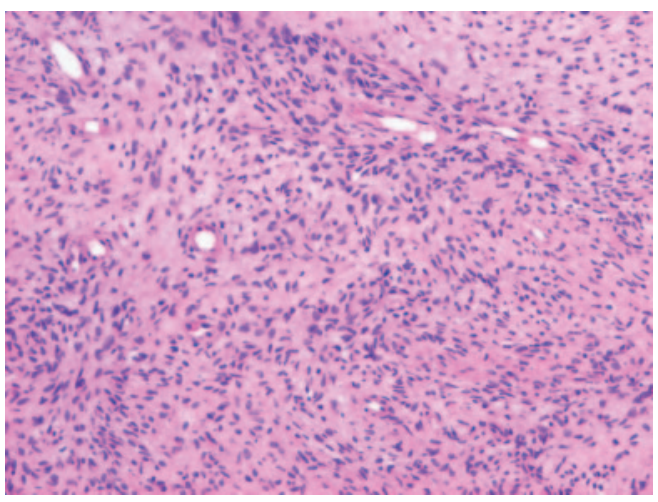

Pathologic examination showing a spindle cell tumor with areas of collagen and clearer areas of myxoid type.

A 49-year-old woman had received radiotherapy at the axillar, clavicular, and left laterocervical regions for Hodgkin lymphoma. Fifteen years later, she reported progressive loss of strength and sensation in her left arm. The patient had no stigma of neurofibromatosis or any other genetic mutation.

Cervical MRI showed neurofibromas (figure 1). A cervical laminectomy was performed and multiple neurofibromas were resected. The pathologic examination confirmed the diagnosis of neurofibromas (figure 2).

Only 9 cases of radioinduced neurofibromas have been documented to date. ${ }^{1,2}$ Our patient has the largest number of nerves affected. ${ }^{2}$ Although rare, radioinduced neurofibromas should be taken into consideration in the differential diagnosis of patients who have undergone radiotherapy and develop progressive neurologic deterioration.

Cristian de Quintana-Schmidt, MD, Pablo Clavel Laria, MD, Barcelona, Spain

Disclosure: The authors report no disclosures.

Address correspondence and reprint requests to Dr. Cristian de Quintana-Schmidt, Resident of the Department of Neurosurgery, Sant Pau Hospital (Barcelona), Sant Antoni Maria Claret 167,08025 Barcelona, Spain; cqs_7@hotmail.com

1. Buckle C, Shannon P, Massicotte EM, Wong S, Guha A. Radiation induced peripheral nerve tumors: case series and review of the literature. J Neurooncol 2007;83:205-212.

2. Lai V, Wong YC, Poon WL, Fu YP, Lam TC, Yuen SC. Radiation-induced peripheral nerve neurofibromata in a patient receiving hypofractionated radiation therapy. AJNR Am J Neuroradiol 2008;29:1995-1997. 


\title{
Neurology
}

\author{
Multiple radiation-induced neurofibromas \\ Cristian de Quintana-Schmidt and Pablo Clavel Laria \\ Neurology 2010;75;1214 \\ DOI 10.1212/WNL.0b013e3181f4d7de
}

This information is current as of September 27, 2010

\section{Updated Information \& Services}

References

Subspecialty Collections

Permissions \& Licensing

Reprints including high resolution figures, can be found at: http://n.neurology.org/content/75/13/1214.full

This article cites 2 articles, 1 of which you can access for free at: http://n.neurology.org/content/75/13/1214.full\#ref-list-1

This article, along with others on similar topics, appears in the following collection(s):

MRI

http://n.neurology.org/cgi/collection/mri

Nerve tumor

http://n.neurology.org/cgi/collection/nerve_tumor

Radiation therapy-tumor

http://n.neurology.org/cgi/collection/radiation_therapytumor

Information about reproducing this article in parts (figures,tables) or in its entirety can be found online at:

http://www.neurology.org/about/about_the_journal\#permissions

Information about ordering reprints can be found online:

http://n.neurology.org/subscribers/advertise

Neurology ${ }^{\circledR}$ is the official journal of the American Academy of Neurology. Published continuously since 1951, it is now a weekly with 48 issues per year. Copyright . All rights reserved. Print ISSN: 0028-3878. Online ISSN: 1526-632X.

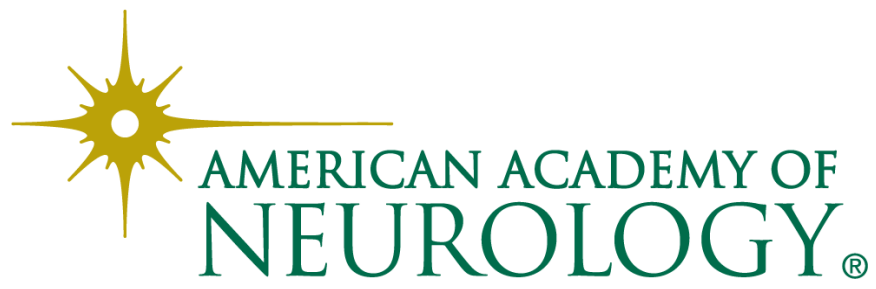

